\title{
Inoculation of Rhizobacteria to Red Chili Plant (Capsicum annum L.) in Saline Sandy Soil
}

\author{
Monica Widianti, Oedjijono, Elly Proklamasiningsih \\ Fakultas Biologi, Universitas Jenderal Soedirman \\ Jalan dr. Suparno 63 Purwokerto 53122 \\ Email: monicawidianti@gmail.com
}

History Article :

Submited : 26/08/2019

Accepted : 31/01/2020

\begin{abstract}
A red chili plant (Capsicum spp.) is one of the horticultural commodities in Indonesia which has good economic value, so it has priority to be developed. Agriculture practices in Java island have partly switched to coastal areas which have characteristics of saline soils. Saline soils are alkaline and nutrient-poor, especially essential nutrients such as $\mathrm{P}$ and N. One way to restore fertility in saline soils used beneficial and fertilizing bacteria such as PGPR. Plant growth-promoting rhizobacteria (PGPR) are free-living, soil-borne bacteria, which are capable of enhancing the growth of the plant either directly or indirectly. The objectives of this research were to determain the effect of PGPR isolates to the growth of red chili plants in saline sandy soil and to determine the best PGPR isolate capable to improve the growth of red chili plant in saline sandy soil. The result showed that the inoculation of rhizobacteria significantly affected to plant height and root length of the red chili plant (Capsicum annum). The combination of 3 PGPR isolates (Azospirillum PSA 10, Azotobacter PSA 8, and Marinococcus PSA 1) was the best result in increasing the height and root length of the chili plant (Capsicum annum).

Keywords: red chili plant (Capsicum annum), PGPR, Saline soil.
\end{abstract}

\section{INTRODUCTION}

Salinity causes problems for plants in saline soils because of the excessive concentration of dissolved salt in the soil, which causes water difficult to be absorbed by plants, resulting in low turgor pressure. This resulted in a deterioration in plant growth, and changes in anatomical and physiological characteristics (Yulianto et al., 2017). The osmotic pressure of saline soil is also one of the natural problems that adversely affected plant growth (Hadijah, 2014). Coastal areas would have the potential for red chili plant cultivation if it managed properly. Certain techniques are needed to improve the growth of plant crops. One way to restore fertility in saline soils used beneficial and fertilizing bacteria such as PGPR (Widawati, 2015). Plant growth-promoting rhizobacteria (PGPR) are free-living, soil-borne bacteria, which are capable of enhancing the growth of the plant either directly or indirectly (Kanchana et al., 2014; Pii et al., 2015).

These bacteria are also known to colonize plant roots actively. The roles of PGPR for plants are: 1) as a biofertilizer, PGPR can accelerate the process of plant growth through accelerating nutrient absorption, 2) as bio-stimulants, PGPR can stimulate plant growth through phytohormones production and 3) as a bioprotectant, PGPR protects plants from pathogens (Rai, 2006). PGPR includes several bacteria such as Rhizobium, Azospirillum, Azotobacter. Azotobacter sp. PSA 8 and Azospirillum sp. PSA 10 was known capable of synthesizing growth-promoting hormone or phytohormo ne such as Indole Acetic Acid (auxin), capable of fixing atmospheric nitrogen and dissolving phosphate. Marinococcus sp. PSA 1 was aerobic, have cocci cells, Gram-positive, irregular colony shape, and it can dissolve phosphate. The bacterium was known as saline halotolerant, which was capable of growing in medium containing $5 \%$ $\mathrm{NaCl}$ (Kusumawardhani, 2018). The objectives of this research were to determaine the effect of PGPR isolates to the growth of red chili plants in saline sandy soil and to determine the best PGPR isolate is able to improve the growth of red chili plant in saline sandy soil.

\section{MATERIAL AND METHOD}

\section{Subculture}

Azospirillum sp. PSA 10 was subcultured on Caceres agar medium, Azotobacter sp. PSA 8 was subcultured on Ashby mannitol agar medium, and Marinococcus sp. PSA 1 was subcultured on Pikovskaya medium. The cultures were incubated for $2 \times 24$ hours at room temperature (Widawati et al., 2015; Hindersah et al., 2016).

\section{Measurement of Salinity Soil}

The saline sandy soil was sampled from the Sodong beach area, Cilacap. Soil salinity was measured using a calibrated hand refractometer (Martiningsih et al., 2015; Putra et al., 2018).

\section{Seedling preparation}

The saline sandy soils were taken then dried and sifted evenly. The sandy soil was mixed with manure with a ratio of 2: 1 then sterilized in drum sterilizer. Selected red chili seeds (Panex F1 100) with uniform size were planted on the planting 
medium slowly and then covered with soil. The seedling that has been grown or already had 3-4 leaves or after 21-24 days were selected for the further experiment (Widayanthi et al., 2017).

\section{Inocula Preparation}

Amount of 1 loop of the culture of Azospirillum sp. PSA 10., Azotobacter sp. PSA 8 from the nutrient agar medium was inoculated to nutrient broth medium and incubated in the shaker incubator (150 rpm, room temperature) for 1 x 24 hours at room temperature. Amount of 1 loop of the culture of Marinococcus sp. PSA 1 was inoculated in nutrient agar medium with streak continues method then incubated for $1 \times 24$ hours at room temperature. Amount of 3-4 mL of aquadest was added onto the cultures that already incubated and scraped off using drugalsky, the solutions were placed in a test tube. The amount of $1 \mathrm{~mL}$ solution was taken and inoculated in $20 \mathrm{~mL}$ nutrient broth medium. The population of bacterial inoculum was determined as many as $10^{8} \mathrm{CFU} / \mathrm{mL}$ by spectrophotometric method.

\section{Inoculation of red chili plant with PGPR isolates}

Selected seedling was planted in a polybag with a diameter of $25 \times 20 \mathrm{~cm}$ which contained saline sandy soil. The roots of selected red chili seedlings were planted in the polybag in an upright position. The amount of $2 \mathrm{~mL}$ of liquid bacterial isolates with a population of $10^{8} \mathrm{CFU} / \mathrm{mL}$ was sprayed onto the roots in each polybag (Widayanthi et al., 2017).

This research was conducted experimentally using a Completely Randomized Design (CRD) with 8 treatments. Each treatment was repeated 3 times. The treatments were comprised of as follows:

1. Control (chili plants without inoculation of PGPR isolates).

2. Red chili plants inoculated with Azospirillum sp. PSA 10.

3. Red chili plants inoculated with Azotobacter sp. PSA 8.

4. Red chili plants inoculated with Marinococcus sp. PSA 1.

5. Red chili plants inoculated with mixture of Azospirillum sp. PSA 10 and Azotobacter sp. PSA 8.

6. Red chili plants inoculated with mixture of Azotobacter sp. PSA 8 and Marinococcus sp. PSA 1.

7. Red chili plants inoculated with mixture of Azospirillum sp. PSA 10 and Marinococcus sp. PSA 1.

8. Red chili plants inoculated with mixture of Azospirillum sp. PSA 10, Azotobacter sp. PSA8, and Marinococcus sp. PSA 1.

\section{Maintenance of Seedling}

Maintenance of red chili seedling included watering and weeding. Watering plants were done in the morning and evening or at necessary by spraying water using a hand sprayer. Seedlings that are growing poorly or are not in good condition were replaced with other healthy seedlings. Weeding was done manually to control weeds. Maintenance of the seedling for 35 days in the greenhouse.

\section{Measurement of Plant Growth}

Measurement of plant height was done by measuring the height of chili plants from the base of the stem to the highest shoot using a ruler. The root length measurement was done by measuring the length of the root from the root base to the tip of the root using a ruler (Widayanthi et al., 2017).

\section{RESULT AND DISCUSSION}

The media used for the growth of red chili plants were prepared based on the results of measurements of salinity soil on the Sodong beach Cilacap. The Sodong beach soil had the salinity of 0.5 dS/m. Rachman et al. (2018); Sitorus (2012); Thohiron \& Prasetyo (2012), stated that the salinity content is classified as very low if it has an Electrical Conductivity value $<1 \mathrm{dS} / \mathrm{m}$. Coastal areas usually contained saline soil because there were influenced by tides. Low salinity in coastal areas was due to natural leaching of salt by rainwater, because the sodium contained in saline soil was diluted.

The result of this research showed that the growth of red chili was significantly affected following the application of PGPR isolates especially in increasing the plant height and root length based on Analysis of Variance (ANOVA) at $5 \%$. This result indicated that PGPR isolates could provide nutrients for plants such as $\mathrm{P}$ and $\mathrm{N}$ and to produce phytohormone, so they can increase the plant growth. PGPR isolates used were might be able to trigger root development, so that supports absorbing more nutrients and affect plant height. Kusumawardhani (2018) reported that Azospirillum sp. PSA 10 and Azotobacter sp. PSA 8 were capable to fix nitrogen, dissolve phosphate, and produce phytohormones such as IAA, while Marinococcus sp. PSA 1 could fix nitrogen and dissolve phosphate. In addition, Azospirillum sp. PSA 10, Azotobacter sp. PSA 8, and Marinococcus sp. PSA 1 was resistant to salinity of $\mathrm{NaCl} 5 \%$.

Iswati (2012) found that the addition of PGPR significantly affected the root length of tomato plants. A'yun et al. (2013) reported that PGPR (Azotobacter sp.) had a significant effect on the chili plant's height. The combination treatment of PGPR isolates (Azospirillum sp. PSA 10, Azotobacter sp. PSA 8, Marinoococcus sp. PSA 1) showed the highest root length and plant height of 9.4 and 14.9 $\mathrm{cm}$ (Table 1). This indicated that the PGPR consortium was able to stimulate the chili $(C$. annum) plant height. Anggarwulan et al. (2008) also found that the consortium of PGPR isolates was able to stimulate plant growth because bacterial 
consortium has an excellent synergistic correlation in the availability of $\mathrm{N}$ and $\mathrm{P}$ elements. Aiman et al. (2017) and Mukhtar et al. (2019) reported that Azospirillum sp., Azotobacter sp., and Marinococcus sp., could fix nitrogen, dissolve phosphate, and produce phytohormone thus if the plant inoculated by PGPR consortium produced better plant yield.

Table1. The Average of Red Chili Root Length and Plant Height Inoculated with PGPR isolates

\begin{tabular}{lcc}
\hline \multicolumn{1}{c}{ Treatments } & Root Length $(\mathrm{cm})$ & Plant Height $(\mathrm{cm})$ \\
\hline Kontrol & $3.6667 \mathrm{~b}$ & $9.0000 \mathrm{~b}$ \\
PSA 10 & $6.6000 \mathrm{ab}$ & $13.6333 \mathrm{a}$ \\
PSA 8 & $4.6667 \mathrm{~b}$ & $12.8333 \mathrm{a}$ \\
PSA 1 & $4.5667 \mathrm{~b}$ & $13.5667 \mathrm{a}$ \\
PSA $10+$ PSA 8 & $5.0000 \mathrm{~b}$ & $11.1667 \mathrm{ab}$ \\
PSA $10+$ PSA 1 & $5.1667 \mathrm{~b}$ & $12.6667 \mathrm{a}$ \\
PSA $8+$ PSA 1 & $3.7333 \mathrm{~b}$ & $12.3333 \mathrm{ab}$ \\
PSA 1 + PSA 8 + PSA 10 & $9.4000 \mathrm{a}$ & $14.9333 \mathrm{a}$ \\
\hline
\end{tabular}

Notes: The numbers accompanied by different letters indicate significant differences at LSD $5 \%$.

A consortium of PGPR bacteria (Azospirillum sp. PSA 10, Azotobacter sp. PSA 8, Marinoococcus sp. PSA 1) were known to have an ability to fix nitrogen, dissolve phosphate, and produce phytohormones such as IAA (Kusumawardhani, 2018). IAA is an active form of the auxin hormone found in plants and served to enhance cell development, stimulate the formation of new roots and stimulate growth.

PGPR saline-resistant bacteria can help plant growth in extreme environments to obtain the required elements such as $\mathrm{N}$ and $\mathrm{P}$. The $\mathrm{N}$ element is absorbed by plant roots in the form of ammonia $\left(\mathrm{NH}_{3}\right)$, but $\mathrm{N}$ element was available in the form of $\mathrm{N}_{2}$ in the air. The mechanism of $\mathrm{N}$ fixing by the PGPR bacteria was by converting $\mathrm{N}_{2}$ from the atmosphere into ammonia aided by the nitrogenase enzyme (Widawati et al., 2015). PGPR hydrolyze organic $\mathrm{P}$ into inorganic forms, such as in the form of orthophosphate $\left(\mathrm{H}_{2} \mathrm{PO}_{4}\right.$ and $\left.\mathrm{HPO}_{4}{ }^{2-}\right)$, through the secretion of organic acid, produce phosphatase enzymes such as phosphomonoesterase enzymes and phytase enzymes which responsible for the hydrolysis of organic phosphate into inorganic phosphates. The presence of supply $\mathrm{N}$ and $\mathrm{P}$ elements as nutrients available in the soil can, therefore, help the plant growth.

Based on Least Significant Difference (LSD) analysis at $5 \%$ of plant height and root length of red chili plant (C. annum) showed that the combination treatment of PGPR isolates showed the best result followed by Azospirillum sp. PSA 10, Marinoccocus sp. PSA 1, and Azotobacter sp. PSA 8. Kusumawardhani (2018) reported that Azospirillum sp. PSA 10, Marinoccocus sp. PSA 1, and Azotobacter sp. PSA 8 was capable of fixing nitrogen. Azospirillum PSA 10 was able to dissolve phosphate higher than Azotobacter sp. PSA8. According to Oedjijono et al. (2012), members of the genus Azospirillum sp. can fix nitrogen more dominant than other nitrogen-fixing bacteria. Widawati et al. (2015) stated that Azospirillum sp. bacteria could live and spread widely in the rhizospheric area in several soil ecosystems. Their population was higher in plant rhizosphere than other rhizospheric bacteria.

The ability of Marinococcus sp. PSA 1 in dissolving phosphate was higher than Azotobacter sp. PSA 8 (Kusumawardhani, 2018). Marinococcus sp. is moderate halophilic bacteria means that the bacterium could adapt to a wide range of salt concentrations (Shin et al., 2016). Marinococcus sp. had a metabolite that functions as osmoprotectant such as ectoine, which able to reverse the plant growth inhibition caused by osmotic stress (Rai, 2000).

\section{CONCLUSION}

Based on the results obtained, it can be concluded that PGPR isolates affected the height and root length of Chili plant in saline sandy soil. The combination of PGPR isolates of Azospirillum sp. PSA 10, Azotobacter sp. PSA 8, and Marinococcus sp. PSA 1 showed the highest result in increasing the height, and root length of Chili plants in saline sandy soil.

\section{REFERENCES}

Aiman, U., Tantriati., Sriwijaya, B. 2017. Pemberian Macam Konsorsium Bakteri Hasil Isolasi Tumbuhan Pantai pada Kangkung (Ipomoea reptans Poirs.). Planta Tropika jurnal agribisnis, 5(1), pp. 1-6.

Anggarwulan, Solichatun, \& Widya, M. 2008. Karakter Fisiologi Kimpul (Xanthosoma sagittifolium L. Schott) pada Variasi Naungan dan Ketersediaan Air. Biodiversitas, 9(4), pp. 267-268. 
A'yun, K.Q., Tutung, H. \& Mintarto, M. 2013. Pengaruh Penggunaan PGPR (Plant Growth Promoting Rhizobacteria) Terhadap intensitas TMV (Tobacco Mosaic Virus), Pertumbuhan, dan Produksi Pada Tanaman Cabai Rawit (Capsicum frutescens L.). Jurnal Hama Penyakit Tanaman, 1(1), pp. 47-55.

Hadijah, M.H. 2014. Peran Mikoriza Acacia auriculiformis yang Ditumbuhkan pada Tanah Salin. Jurnal Ilmiah Agribisnis dan Perikanan, 7(1), pp. 1-9.

Hindersah, R., Priyanka, Rumahlewang, W., \& Kalay, A.M. 2016. Selection and Bioassay of Azotobacter sp. Isolates to Improve Growth of Chili (Capsicum annum L.) on Entisols in Ambon. Journal of Microbiol Indones., 10(4), pp. 125-130.

Iswati, R. 2012. Pengaruh Dosis Formula PGPR Asal Perakaran Bambu terhadap Pertumbuhan Tanaman Tomat (Solanum lycopersicum syn). JATT, 1(1), pp. 9-12.

Kanchana, D. Jayanthi, M., Usharani, G., Saranraj, P. \& Sujitha, D. 2014. Interaction Effect of Combined Inoculation of Pgpr on Growth and Yield Parameters of Chilli Var K1 (Capsicum annuum L.). International Journal of Microbiological Research, 5(3), pp. 144-151.

Kusumawardhani, D. 2018. Isolasi dan Karakterisasi Bakteri Perakaran Tanaman Padi Lahan Salin Sebagai Kandidat PGPR. Skripsi. Purwokerto: Fakultas Biologi UNSOED.

Martiningsih, N.G.A.G.E., Suryana, I.M., \& Sutiadipraja, N. 2015. Analisa Vegetaso Hutan Mangrove di Taman Hutan Raya (Tahura) Bali. Jurnal Agrimeta, 5(9), pp. 113.

Mukhtar, S. Mehnaz, S., \& Malik, K.A. 2019. Microbial diversity in the rhizosphere of plants growing under extreme environments and its impact on crop improvement. Environmental Sustainability 2, pp. 329-338.

Oedjijono, Lestanto, U.W., Erie, K.N. \& Bondansari. 2012. Pengaruh Azospirillum spp. Terhadap Pertumbuhan Tanaman Jagung (Zea mays) dan Kemampuan Beberapa Isolat dalam Menghasilkan IAA. Prosiding Seminar Nasional, pp. 157-163.

Pii, Y., Mimmo, T., Tomasi, N., Terzano, R., Cesco, S., \& Crecchio, C. 2015. Microbial interactions in the rhizosphere: beneficial influences of plant growth-promoting rhizobacteria on nutrient acquisition process. Biol Fertil Soils., 51, pp. 403-415.
Putra, R., Muhammad., Huzni, S., \& Fonna, S. 2018. Pengaruh Faktor Lingkungan terhadap Potensi Korosi pada Pipa Air Bawah Tanah di Jalur Krueng Peusangan hingga Krueng Geukueh, Aceh Utara. Flywheel: Jurnal Teknik Mesin Untirta, IV(1), pp. 14 - 19.

Rachman, A., Dariah, A., \& Sutono, S. 2018. Pengolahan Sawah Salin Berkadar Garam Tinggi. Jakarta: IAARD Press.

Rai, M. 2000. Biosynthesis of 1,4,5,6-Tetrahydro-2Methyl 4-Pyrimidinecarboxylic Acid (Ectoine) from Marinococcus halophilus into Tobacco. Journal of New Seeds, 2(1), pp 1541.

Rai, M.K., 2006. Handbook of Microbial Biofertilizer. New York: Food Production Press.

Shin, W., Siddikee, A., Joe, M.M., Benson, A., Kim, K., Selvakumar, G., Kang, Y., Jeon, S., Samaddar, S., Chatterjee, P., Walitang, D., Chanratanam M., Sa, T. 2016. Halotolerant Plant Growth Promoting Bacteria Mediated Salinity Stress Amelioration in Plants. Korean J Soil Sci Fert, 49(4), PP. 355-367

Sitorus, T.A. 2012. Analisis Salinitas dan Dampaknya Terhadap Produktivitas Padi di Wilayah Pesisir Indramayu. Skripsi. Bogor: Institut Pertanian Bogor.

Taufik, M., Hidayati, S.H., Suastika, G., Sumaraw, S.M., \& Sujiprihati, S. 2005. Kajian Plant Growth Promoting Rhizobacteria sebagai Agens Proteksi Cucumber Mosaic Virus dan Chilli Veinal Mottle Virus pada Cabai. Hayati, 12(4), pp.139-14.

Thohiron, M \& Prasetyo, H. 2012. Pengelololaan Lahan dan Budidaya Tanaman Lahan Terdampak Lumpur Marine Sidoarjo. J-PAL, 3(1), pp. 19-27.

Tuteja, N. 2007. Mechanism of High Salinity Tolerance in Plants. Methods in Enzymology, 428, pp. 419.438.

Widawati, S. 2015. Peran Bakteri Fungsional Tanah Salin (PGPR) pada Pertumbuhan Padi di Tanah Berpasir Salin. Prosiding Seminar Nasional Biodiversitas Indonesia, 1(8), pp. 1856-1860.

Widawati, S., Suliasih \& Saefudin. 2015. Isolasi dan uji efektivitas Plant Growth Promoting Rhizobacteria di lahan marginal pada pertumbuhan tanaman kedelai (Glycine max L. Merr.) var. Wilis. Prosiding Seminar Nasional Biodiversitas Indonesia, 1(1), pp. 59-65. 
BioEksakta: Jurnal Ilmiah Biologi Unsoed

Volume 2, Nomor 2 (2020): 261 - 265

Widayanthi, N.K.A., Raka, I.G.N. \& Siadi, I.K. 2017. Pengaruh Dry Heat Treatment dan Pengokeran Terhadap Pertumbuhan dan Kesehatan Bibit Cabai Rawit (Capsicum frutescens L.). E-jurnal Agroteknologi Tropika , 6(1), pp. 52-61.

Yulianto, R., Yamika, W.S. \& Aini, N. 2017. Pengaruh Amelioran Tanah pada Pertumbuhan Tanaman Kedelai (Glycine max L.) pada Kondisi Salinitas. Jurnal Produksi Tanaman, 5(2), pp. 232-239.

Yuniati, R. 2004. Penapisan Galur Kedelai Glycine $\max (\mathrm{L}$.$) Merrill Toleran Terhadap \mathrm{NaCl}$ untuk Penanaman di Lahan Salin. Makara Sains, 8(1), pp. 21-24. 